$1-2005$

\title{
Signaling and Precedent in Federal District Court Opinions
}

Andrew P. Morriss

Texas A\&M University School of Law, amorriss@law.tamu.edu

Michael Heise

Gregory C. Sisk

Follow this and additional works at: https://scholarship.law.tamu.edu/facscholar

Part of the Law Commons

\section{Recommended Citation}

Andrew P. Morriss, Michael Heise \& Gregory C. Sisk, Signaling and Precedent in Federal District Court Opinions, 13 Sup. Ct. Econ. Rev. 63 (2005).

Available at: https://scholarship.law.tamu.edu/facscholar/248

This Article is brought to you for free and open access by Texas A\&M Law Scholarship. It has been accepted for inclusion in Faculty Scholarship by an authorized administrator of Texas A\&M Law Scholarship. For more information, please contact aretteen@law.tamu.edu. 


\title{
Signaling and Precedent in Federal District Court Opinions
}

\author{
Andrew P. Morriss* ${ }^{*}$ Michael Heise ** and Gregory C. Sisk***
}

Standard economic analysis of judicial behavior, at least with respect to federal judges, has to some extent foundered on the apparent success of the Constitution's framers in designing an institution where almost the whole thrust of the rules governing compensation and other terms and conditions of judicial employment is to divorce judicial action from incentives. That is, the structure takes away the carrots and sticks and the different benefits and costs associated with different behaviors which inform human action in an economic model. Nonetheless, our earlier empirical work, as well as work by others, found significant associations between promotion potential and judicial decision making in the federal district bench. This earlier work left unclear, however, how district judges might use their positions to enhance their opportunities for advancement. In this paper we examine how federal judges can use the content and outcome of their decisions to signal that they would be appropriate candidates for elevation to a higher court. We first develop a framework that explains how judges can use decisions and opinions to signal to appointing authority. We then test the theory through a de-

* Galen J. Roush Professor of Business Law \& Regulation, Case Western Reserve University School of Law, e-mail: andrew.morriss@case.edu. Thanks to Tom Baker, Frank Cross, Jonathan Entin, Tracey George, Stephen Wasby, the anonymous referees, and seminar participants at the Department of Agricultural Economics and Economics, Montana State University, especially Terry Anderson, Andrew Hanssen, Dean Lueck, and Ian Wills, for comments on earlier drafts.

* * Professor of Law, Cornell Law School, e-mail: mrh38@cornell.edu.

* * Professor of Law, University of St. Thomas School of Law (Minneapolis), e-mail: gcsisk@stthomas.edu. 
tailed examination of federal district judges' behavior in their decisions on the constitutionality of the sentencing guidelines during the "Sentencing Guidelines Crisis of 1988." Examining judges' decisions to rule through a written opinion, we find evidence supporting the signaling hypothesis. Judges were more likely to use written opinions to communicate their rulings in Sentencing Guidelines cases where the potential for promotion to the circuit court of appeal was greater. We also find that precedent influences outcome but not the particular reasons judges articulate for their decisions

\section{INTRODUCTION}

That judges' self-interest might influence judicial opinions often has been neglected in the research literature. ${ }^{1}$ Economic analysis of judicial behavior, at least with respect to federal judges, has to some extent foundered on the apparent success of the Framers of the Constitution in successfully designing an institution where

almost the whole thrust of the rules governing compensation and other terms and conditions of judicial employment is to divorce judicial action from incentives-to take away the carrots and sticks, the different benefits and costs associated with different behaviors, that determine human action in an economic model. ${ }^{2}$

Nonetheless, our earlier empirical work ${ }^{3}$ as well as work by others ${ }^{4}$ found significant associations between promotion potential and judicial decision making in the federal district bench. This earlier work left unclear, however, how district judges might use their positions to enhance their opportunities for advancement. In this paper we examine how federal judges can use the content and outcome of their decisions to signal that they would be appropriate candidates for elevation to a higher court. We first develop a framework that explains how

${ }^{1}$ Frederick Schauer, Incentives, Reputation, and the Inglorious Determinants of Judicial Behavior, 68 U Cinc L Rev 615, 615 (2000).

${ }^{2}$ Richard A. Posner, What Do Judges Maximize? (The Same Thing Everybody Else Does), 3 Sup Ct Econ Rev 1, 1 (1993). See also Richard A. Epstein, The Independence of Judges: The Uses and Limitation of Public Choice Theory, 1990 BYU L Rev 827 (1990).

${ }^{3}$ Gregory C. Sisk, Michael Heise, and Andrew P. Morriss, Charting the Influences on the Judicial Mind: An Empirical Study of Judicial Reasoning, 73 NYU L Rev 1377 (1998).

${ }^{4}$ Mark A. Cohen, The Motives of Judges: Empirical Evidence from Antitrust Sentencing, 12 Int Rev L \& Econ 13 (1992); Mark A. Cohen, Explaining Judicial Behavior or What's "Unconstitutional" about the Sentencing Commission! 7 J L, Econ, \& Org 183 (1991). 
judges can use decisions and opinions to signal to appointing authority. We then test the theory through a detailed examination of federal district judges' behavior in their decisions on the constitutionality of the sentencing guidelines during the "Sentencing Guidelines Crisis of 1988."

Examining judges' decisions to rule through a written opinion, we find evidence supporting the signaling hypothesis. Judges were more likely to use written opinions to communicate their rulings in Sentencing Guidelines cases where the potential for promotion to the court of appeals was greater. We also find that precedent influences outcome but not the particular reasons judges articulate for their decisions.

\section{PROMOTING JUDGES}

The judiciary in the United States is organized in a series of parallel, hierarchical structures. At the top of the federal system in terms of prestige, compensation, and power is the United States Supreme Court, followed by the Federal Courts of Appeals, the Federal District Courts, and assorted specialized and subordinate judicial positions (the Court of Federal Claims, Magistrate Judges, Bankruptcy Judges, and similar positions). Table 1 lists federal judicial positions, their number, their terms, and their salaries. ${ }^{5}$

Although attaining a promotion within the federal judicial system requires different things at different levels and at different times, appointment to higher positions in the federal system is largely a political process. All appointments at the district court level and above are formally made by the President with the advice and consent of the Senate. Appointments to the federal district bench have traditionally been made subject to a large degree of deference to political leaders in the state where the judge will sit. ${ }^{6}$ Appointments to the courts of appeals feature a lesser but still positive degree of deference to political leaders for the state in which the judge sits, although a circuit judge will have authority over a multi-state geographic region. ${ }^{7}$ Finally appointments to the U.S. Supreme Court are the most politicized and, at least in recent years, reflect interest group pressure at the national

${ }^{5}$ State judiciaries are organized in a roughly similar fashion, with the most prominent differences being that a substantial minority of states lack an intermediate appellate court and two states (Texas and Oklahoma) have parallel courts of last resort for civil and criminal law issues. (State judges are also selected in a variety of ways and have different term lengths.)

${ }^{6}$ Sheldon Goldman, Picking Federal Judges: Lower Court Selection from Roosevelt Through Reagan 13 (Yale, 1997).

'Id. 
Table 1. Federal Judicial Positions in 1988

\begin{tabular}{|c|c|c|c|c|}
\hline Position & Number & Compensation & Appointed By & Term \\
\hline $\begin{array}{l}\text { Chief Justice, } \\
\text { Supreme Court }\end{array}$ & 1 & $\$ 115,000$ & President & Life \\
\hline $\begin{array}{r}\text { Associate Justice, } \\
\text { Supreme Court }\end{array}$ & 8 & $\$ 110,000$ & President & Life \\
\hline $\begin{array}{l}\text { Judge, Circuit Court } \\
\text { of Appeals }\end{array}$ & 179 & $\$ 95,000$ & President & Life \\
\hline $\begin{array}{l}\text { District Judge (including } \\
\text { temporary seats) }\end{array}$ & 655 & $\$ 89,500$ & President & Life \\
\hline Bankruptcy Judge & 309 & $\$ 72,500$ & $\begin{array}{l}\text { Circuit Court } \\
\text { of Appeal } \\
\text { Judges }\end{array}$ & $\begin{array}{l}14 \text { years, } \\
\text { renewable }\end{array}$ \\
\hline Magistrate Judge & $\begin{array}{l}292 \text { full } \\
\text { time } \\
164 \text { part } \\
\text { time }\end{array}$ & $\begin{array}{l}\$ 72,500 \\
\quad \text { (full time) }\end{array}$ & $\begin{array}{l}\text { District Court } \\
\text { Judges }\end{array}$ & $\begin{array}{l}8 \text { years, } \\
\text { renewable } \\
\text { (full time); } \\
4 \text { years } \\
\text { renewable } \\
\text { (part time) }\end{array}$ \\
\hline
\end{tabular}

level. Interest groups are increasingly playing a role in appointments to the lower courts as well.

Because the number of judicial positions declines sharply as one ascends the ladder of prestige in the federal system, the number of opportunities for promotion also declines sharply. Accordingly we focus here on the promotion of federal district judges to the federal appellate courts. ${ }^{8}$ There are 179 circuit court judgeships and 655 district court judgeships in the United States today. Circuit court vacancies need not be filled from the district court bench, but they often are. During most of the circuit courts of appeals' existence, between forty to sixty percent of federal circuit appointees have prior experience as a federal district judge. ${ }^{9}$ In the 1980 s, the period covered by our data, the percentage was around $38 \% .^{10}$ Although there are relatively few circuit judgeships available compared to district judgeships (a roughly constant ratio of 1:3.5 has existed for some time), there are enough vacancies that promotion remains a real possibility for most district judges. In circuits where a vacancy exists or is likely to exist, promotion is a distinct possibility for district judges.

${ }^{8}$ District judges could be promoted directly to the Supreme Court, without first serving on the appellate bench, and several have been mentioned on short lists for appointment to the Supreme Court in recent years, although none were nominated.

${ }^{9}$ Daniel Klerman, Nonpromotion and Judicial Independence, 72 So Cal L Rev 455, 460 (1999).

${ }^{10} \mathrm{Id}$. 
There are many paths to judicial selection and promotion. Political appointments in general are often awarded based on partisan political services. Once on the federal bench, however, partisan activities are generally not available to a judge desiring promotion since the rules governing federal judges forbid political activity. While prior political service or connections can still help, the potential for political service while on the bench is severely limited. Judicial ethics also forbid the public discussion of how a judge will vote in a particular type of case that might arise in the future, leading to somewhat bizarre proceedings in confirmation hearings in which nominees attempt to establish that they have not considered particular politically charged issues enough to have prejudged the issues. ${ }^{11}$ While the signals sent before appointment to a district court position are capable of influencing the appointing authority, additional signals from political activity are not available in the competition for appointment to a higher court. District court judges are thus limited in their ability to compete for circuit court of appeals vacancies through the type of signals they used to obtain their district court appointments. ${ }^{12}$

Within the context of their judicial role, however, judges have regular opportunities to signal their qualifications for promotion through their judicial decisions. Popular and scholarly accounts of judicial nominations suggest that opinions are carefully screened before promoting a lower court judge. ${ }^{13}$ Discussions of judicial appointments often center on the alleged use of "litmus tests" for screening potential judicial candidates, particularly with respect to abortion. For example, abortion rights pressure groups demand that potential judges swear allegiance to Roe $v$. Wade while pro-life pressure groups insist on a commitment to overturning that decision. Since potential judges cannot openly discuss how they would handle such questions in the future, people involved in selection processes both within and with-

11 Neil A. Lewis, Eating His Words, Houston Chronicle 22 (December 29, 1991).

${ }^{12}$ A decision which attracts attention from the nominating authority may also attract unwelcome attention from opponents of the President in the Senate. We do not think such considerations would prevent judges from making use of opinions as signals. Given the substantial competition for the limited number of appellate court positions, the wise judge will see that it is vital to draw the attention of the administration in whatever way reasonably possible, leaving concerns about opposition in the Senate to another day. In other words, it indeed is the door to nomination that is most difficult to get through, so more energy and attention will be focused on that stage. Further, only forty percent of vacant circuit judgeships in recent years were filled from the ranks of district court judges, while the vast majority of circuit nominees were confirmed in the 1980s. The critical step is thus, we believe, attracting executive branch attention, not remaining a stealth candidate for the confirmation process.

${ }^{13}$ Carl Tobias, Filling the Federal Courts in an Election Year, 49 SMU L Rev 309 (1996). 
out the government often turn to candidates' records, particularly past decisions, for clues as to how a judge will behave in the future. ${ }^{14}$ (Outside writings, of course, also play a role, as Robert Bork discovered to his chagrin.)

One difficulty with promotion potential as a variable is that it operates unevenly across judges. Experiences for district and appellate judges differ widely. Although an appellate judgeship pays more and carries more prestige, being a federal appellate judge is a more isolated experience than being a federal district judge. Appellate judges have contact primarily with other appellate judges and the various judges' law clerks and staffs. District judges, on the other hand, have regular contact with the bar and members of the public. Appellate judges decide cases largely based on written materials (briefs and memos), with comparatively brief oral arguments. Chambers conferences with their clerks are their primary chance to interact with nonjudges on a case. District judges spend considerable time in the courtroom and conferences with lawyers. There are thus some, and perhaps a substantial number, of district judges who would not be willing to serve as appellate judges. ${ }^{15}$ Unlike the opportunity for additional monetary compensation, therefore, the incentive of a "promotion" to the circuit court is not universally desired. Taking this into account strengthens the impact on those district judges desiring promotionremoving half the pool of potential competitors for promotion, for example, would double the opportunities for promotion. Because we could construct no way to measure whether any particular district judge desired promotion, we are forced to set aside the unevenness of the desire for promotion in our empirical analysis below. Since we find significant evidence of the influence of promotion potential despite this diluting consideration, we do not believe this is a problem here, although it merits further analysis and consideration in future studies.

Signals sent through opinions are not costless, of course. Writing an opinion that both decides a legal issue and sends an appropriate signal may be more difficult than writing one that only resolves the issue. Signals must be carefully crafted, for opinions will be analyzed by not only the appointing authority but by the president's opponents

${ }^{14}$ See Jonathan L. Entin, The Confirmation Process and the Quality of Political Debate, 11 Yale L \& Pol Rev 407 (1993), for a discussion of the rise of the ideological model of the confirmation process at the Supreme Court level.

${ }^{15}$ District judges have the opportunity to experience the appellate lifestyle on occasion by sitting on appellate panels "by designation" to provide the relevant circuit court of appeals with additional personnel. Some district judges seek such opportunities while others actively avoid them. 
in the Senate, who will be searching for nominees who can be defeated. This scrutiny requires care in drafting and lifts opinion writing out of the "cheap talk" signal category.

\section{JUDICIAL UTILITY FUNCTIONS}

Posner posits a judicial utility function based on the utility derived from the acts of judging, leisure, moonlighting, reputation, and other sources of judicial utility such as popularity among lawyers, prestige, and avoiding reversal. ${ }^{16}$ Adding the potential for promotion and utility from creating a precedent, we write a federal district judge's utility as

$$
\mathrm{U}=\mathrm{U}\left(\mathrm{I}_{f}, \mathrm{I}_{v}\left(\mathrm{t}_{v}\right), \mathrm{t}_{j}, \mathrm{t}_{1}, \mathrm{R}, \mathrm{C}, \mathrm{P}, \mathrm{O}\right)
$$

where judicial income (I) is represented by fixed (judicial salary) and variable components (outside income from moonlighting), time spent on leisure $\left(t_{l}\right)$, time spent on judging $\left(t_{j}\right)$, reputation $(R)$, potential for promotion to the circuit court $(\mathrm{C})$, creation of a precedent $(\mathrm{P})$, and other components $(\mathrm{O})$. We further assume that judges allocate their time so that they maximize their utility, making the marginal utility from the last hour devoted to judging equal to the marginal utility of the last hour devoted to leisure. ${ }^{17}$

In evaluating the decision to write an opinion in a particular case, we can narrow the focus of the utility function considerably. In particular, to simplify the model we assume that the decision to write a specific opinion (as opposed to the decision to write an additional opinion) will not have an impact on judicial income, moonlighting, time spent on other aspects of judging, or leisure time. ${ }^{18}$ The utility derived from writing opinion $i$ can therefore be represented by

$$
\mathrm{U}\left(\mathrm{w}_{i}\right)=\mathrm{U}\left(\mathrm{R}\left(\mathrm{w}_{i}\right), \mathrm{C}\left(\mathrm{w}_{i}\right), \mathrm{P}\left(\mathrm{w}_{i}\right)\right)
$$

making the utility from writing opinion $i$ depend only on the opinion's influence on the judge's reputation, its creation of a precedent

${ }^{16}$ Posner, 3 Sup Ct Econ Rev at 31-34 (cited in note 2).

${ }^{17}$ Id at 31 .

${ }^{18}$ We think this is a reasonable assumption. Although opinion writing is a substantial part of judging, judges' time budgets are soft, so that time spent writing opinions need not affect the work/leisure trade-off. For example, since district judges have virtually unlimited authority over their schedules, even an opinion that proved timeconsuming to write need not affect the judging/leisure tradeoff as other cases could simply be shifted into the future. Of course a judge who engaged in prolific opinion writing beyond the norm for judges at his or her level would have to make other tradeoffs. The potential for enhanced income from promotion is assumed to be subsumed within C. 
that fits with the judge's policy preferences, and its impact on the potential for promotion.

For federal district judges, we believe we can narrow the focus still more. The impermanence of district court opinions reduces the impact of the role of precedent on judicial utility. ${ }^{19}$ District judges face the constraint of review by a higher court; Supreme Court justices do not. (Supreme Court opinions are, of course, "reviewed" through academic criticism, but there is little evidence that they are ever "reversed" in a meaningful way through that avenue.) Although this constraint is always present for lower court judges, it is more probable in some cases (those with constitutional issues, for example) that they will be reviewed. Precedent that rests on district court opinions is particularly fragile--no court must follow it and the opportunities to overturn it are frequent. To be sure, the persuasive value of precedent on other district judges may encourage preparation of written decisions designed to convince other judges facing the same issues to reach the same conclusions. Indeed, our prior study found strong evidence of the persuasive impact of sentencing guidelines constitutionality decisions upon other judges. ${ }^{20}$ However, that differs from the Posnerian utility function's implicit assumption that precedent is a means of gaining utility by embedding personal policy preferences in the law. Moreover, the more significant the precedent, the more fragile it is, as the incentives for the losing parties to appeal and appellate court judges to impose their own views grow with the importance of the rule. Because circuit court opinions are more likely to establish lasting precedents, the utility from establishing a legal rule will play a larger role in analysis of those judges' behavior. At the trial court level, however, we believe we can safely ignore the legally controlling nature of precedent, at least in notorious disputes.

Precedent operates in a second way as well, however. District judges write not just to encode their views in the law but to persuade others. Particularly in cases like these, involving constitutional questions that the Supreme Court would decide in the near future, establishing a binding precedent cannot be the reason for writing. Seeking to persuade others, however, provides a motive for writing. Measuring the intensity of the desire to persuade is unfortunately not possible. The circumstances of our data allow us to set this concern aside here. Given

${ }^{19}$ Lower courts do have opportunities to create precedents that, at least until reviewed by higher courts, also establish meaningful new legal rules. Federal district judges, for example, played a significant role in the evolution of Pennsylvania employment law through their decisions in diversity cases. See Mark R. Kramer, Comment: The Role of Federal Courts in Changing State Law: The Employment At Will Doctrine in Pennsylvania, $133 \mathrm{U}$ Pa L Rev 227 (1984).

${ }^{20}$ Sisk, Heise \& Morriss, 73 NYU L Rev at 1493-1498 (cited in note 3). 
the importance of the issue for district judges, ${ }^{21}$ and the presence of background variables that control for the demographic factors we hypothesized might be related to the intensity of feeling (e.g. experience as a prosecutor or defense attorney), we assumed that, after controlling for demographics, the judges in our data set all experienced the benefit of communicating their views to the Supreme Court equally.

Further, because we have captured some of what might be labeled reputation above and in our promotion potential variable discussed below, we can discount for the present purposes the separate influence of decisions on individual reputation as well. A trial judge's reputation depends on many things-his decisions, demeanor in court, reputation for fairness, length of docket, and so on. The influence of any given written opinion on reputation so defined independent of the opinion's service as a signal is therefore likely to be small, even an opinion on an important issue such as the sentencing guidelines.

We have now reduced the decision to write an opinion to its influence on the potential for promotion. ${ }^{22}$ The potential for promotion is a function of the probability that a vacancy exists or will occur soon, for which the judge is eligible and the judge's suitability for the promotion. For simplicity, assume that suitability is a linear sum of the number of opinions in which the judge has taken the "right" position from the point of view of the appointing authority. We can thus write the probability of promotion as

$$
\operatorname{Pr}(\text { Promotion })=\left(\Sigma w_{i}\right) * \operatorname{Pr}(\text { Vacancy })
$$

In this simple model, the marginal value of writing opinion $i$ will therefore be the increase it produces in the probability of promotion:

$$
\partial \operatorname{Pr}(\operatorname{Promotion}) / \partial\left(\mathbf{w}_{i}\right)=\operatorname{Pr}(\text { vacancy })
$$

The higher the probability of a vacancy in the relevant higher court therefore, the greater the value of opinion $i$, if opinion $i$ takes the "correct" position. This is an empirically testable hypothesis. Note that we assume, as we necessarily must for modeling purposes, that district judges have uniform and positive views of the desirability of promotion.

We now turn to the question of whether district court opinions can serve as signals. In Spence's (1974) seminal work on signaling, ${ }^{23}$ he concluded that market signaling games can be divided into two types.

${ }^{21}$ Id.

${ }^{22}$ Some readers may wonder, therefore, why we discussed the other components of the judicial utility function. We found that when we did not, readers suggested that we had neglected these components. We include this discussion to explain why we believe those components are not meaningfully present in this instance.

${ }^{23}$ Michael A. Spence, Market Signaling (Harvard, 1974). 
In the first, the focus of Spence's original model, the game involves relatively large numbers of people in the market at any given time and relative infrequency of any one individual's appearance in the market. Under these conditions, individuals do not invest in signaling credibility because the benefits of doing so are not appreciable. ${ }^{24}$ In the second type of signaling game, where players are relatively few and signals relatively plentiful, individuals invest in reputations because they can appropriate the gains from signaling. ${ }^{25}$

The market for promotion among federal district judges is an example of the second type of signaling. The number of potential appointees to the circuit bench is small, even if all district judges were considered as eligible. (Non-judges are also eligible, of course.) District judges have numerous opportunities to signal through opinion writing, although some opinions will obviously be better signals than others. ${ }^{26}$ Despite their low physical production cost, we do not believe judicial opinions qualify as "cheap talk.".27 As noted above, the signals sent are received by both the appointing and the confirming authorities, whose interests are often dissimilar. There is thus a real cost to a signal that lifts it above "cheap talk." That is, a judge must weigh the possibility that the signal the judge sends may harm the chance for confirmation as well as attract the attention necessary for nomination. As noted earlier, we do not believe such a cost is so high as to prevent judges from sending signals in opinions but it is sufficient to render opinions more than merely "cheap talk."

Judicial decisions have two components. First, decisions are decisions - that is judges decide legal questions. (Posner suggests that the frequency of opportunities to "vote" through decisions is a key element of the utility of the time spent judging. ${ }^{28}$ ) Second, judges also sometimes issue opinions explaining their decisions. Judges thus have a choice in deciding cases about what sort of signal they wish to send. A judge could opt for a decision without an opinion or a decision with an opinion.

While opinions can serve as a signal, both the legal decision made

${ }^{24} \mathrm{Id}$ at 107.

${ }^{25}$ Id at 110 .

${ }^{26}$ Judges can tradeoff the signal quality of their opinion and their desire to create an outcome they prefer in a particular case. District court decisions on factual matters are reviewed under a highly deferential standard while district court legal decisions are decided de novo on appeal. In many cases, outcomes can be "protected" by cloaking them in decisions on the credibility of witnesses and the like, rather than on the law. Factbound decisions, however, send a far noisier signal about judges' views of the law and suitability for promotion.

${ }^{27}$ Joseph Farrell and Matthew Rabin, Cheap Talk, 10 J Econ Persp 103 (1996).

${ }^{28}$ Posner, 3 Sup Ct Econ Rev at 15-18 (cited in note 2). 
and the judicial opinion itself convey information about the deciding judge. In many instances, the opinion contains more information than decision itself. For example, in deciding a constitutional law question, a judge can employ a variety of reasoning approaches to resolving textual ambiguities, and these methods of reasoning may predict future decisions. Thus the Reagan Administration, at least in its Supreme Court appointments, sought to appoint judges committed to originalism in interpretation. Alternatively, a more liberal president might seek to appoint judges committed to the "living constitution" approach advocated by the late Justice William Brennan. ${ }^{29}$ Of course, an existing judicial record is no guarantee against a post-appointment conversion, as appears to have happened with President Nixon's appointment of Harry Blackmun to the Supreme Court. Nevertheless opinions' content does provide some signal of future behavior.

An opinion's content is a particularly important signal in two circumstances. First, many legal questions are readily resolved by resort to binding precedent. No matter how strongly a lower court judge may feel, for example, that Roe v. Wade was incorrectly decided, he or she is still bound by the Supreme Court's opinion in that case until the Supreme Court reverses it. A pro-life judge may therefore be required by $R o e$ and its progeny to strike a particular legislative restriction on abortion regardless of the judge's own preferences. An opinion, however, can signal that the judge carefully explored the opportunities for striking a law before, reluctantly, concluding that he or she is bound by precedent. ${ }^{30}$ Where a binding precedent is controversial, therefore, judges might make use of opinions to signal their disagreement with the substance of the precedent, even while they signal their willingness as lower court judges to follow precedent until they have the opportunity to overturn the particular precedent on a higher court. Many cases, of course, do not allow much potential for sending a signal. Resolving a routine, fact-dependent discovery motion, for example, would be likely to tell a reader little about a judge's philosophy on constitutional issues.

Second, some cases involve legal questions for which there are no

${ }^{29}$ William J. Brennan, The Constitution of the United States: Contemporary Ratification, in Alpheus T. Mason and Donald G. Stephenson, eds, American Constitutional Law (Prentice Hall 8th ed, 1987).

${ }^{30}$ See Margaret $S$ v Edwards, 794 F2d 994 (5th Cir 1986), in which Fifth Circuit Judge Patrick Higginbotham highlighted criticism of Roe v. Wade but concluded that he was constrained by Roe to strike the statute in question. Ironically, anti-abortion groups misread Higginbotham's signal and may have torpedoed his chances for a Supreme Court nomination based on the decision, apparently without reading the opinion. See Neal Devins, Through the Looking Glass: What Abortion Teaches Us About American Politics, 94 Colum L Rev 293, 323 (1994). 
obvious answers dictated by binding precedent. The cases on which we base our empirical analysis below are good examples of that: the question of whether the mandatory service of judges on a presidentially appointed commission violated the Constitution's requirement of separation of powers had never been addressed by the Supreme Court and the existing precedents were ambiguous. ${ }^{31}$ Here a judge's opinion can signal not only his legal craftsmanship but the compatibility of his approach with the appointing authority's preferences.

Both opinions and decisions therefore have the potential to serve as signals. The effectiveness of either will vary with the type of caseopinions in abortion rights cases are much more likely to signal the deciding judges' views than are decisions, because the Supreme Court has removed much of lower courts' discretion through its own opinions. Sentences in criminal cases, as Cohen found in criminal antitrust cases, are better signals of "toughness on crime" than are opinions on the appropriateness of a particular sentence. ${ }^{32}$

Our theory suggests, therefore, that district judges will be more likely to write in cases that send clear signals about their suitability for promotion and be more likely to write when opportunities for promotion are greater. Before turning to the data, however, we must describe the legal controversy on which our empirical results rest.

\section{THE SENTENCING GUIDELINES CRISIS OF 1988}

The Sentencing Reform Act of 1984 ("SRA") revolutionized the sentencing of convicted criminals in the federal courts. During the debate on the Sentencing Guidelines produced by the Sentencing Commission pursuant to the SRA, for example, Representative Mike Synar described the Guidelines as "rewrit[ing] the face of sentencing in this country as we know it, and have known it for over 200 years." ${ }^{\prime 3}$

Prior to the SRA (and for several years after it, while the implementing regulations were being created), federal judges exercised an enormous amount of discretion in sentencing. Federal criminal statutes provided federal district judges with only loose constraints on their decision making, typically allowing a large range of possible sentences. This led to large apparent disparities in sentencing-for example, a study by the Comptroller General of the United States examined sentences given by the United States district courts for the year ending June 30, 1977 and found that the longest average sentence

\footnotetext{
${ }^{31}$ Sisk, Heise \& Morriss, 73 NYU L Rev at $1400-1401$ (cited in note 3).

${ }^{32}$ Cohen, 12 Int Rev L \& Econ 1377 (cited in note 4).

${ }^{33} 133$ Congressional Record 26, 372 (1987).
} 
for bank robbery was 17.9 years, whereas the shortest average sentence was seven years. ${ }^{34}$

The SRA eliminated substantially all of federal district judges' discretion in sentencing, shifting much of it to federal prosecutors in the view of the critics. ${ }^{35}$ In place of the numerous permissible bases for sentences and wide range of possible sentences, the Guidelines issued under the SRA created an extremely narrow range of sentences. Under the Guidelines, sentences for particular offenses are dependent largely on the severity of the offense and the defendant's criminal history. The Guidelines also sharply limited the reasons for which a judge can depart from that narrow range, and granted a right of appeal of sentences to the prosecution. (They also eliminated parole and made other changes.) Judges have compared their roles under the Guidelines to that of notary publics and accountants. ${ }^{36}$

The Guidelines provoked a negative reaction from many federal judges. ${ }^{37}$ Eighty-six percent of federal judges polled by the Federal Judicial Center in 1992 wanted more discretion restored to judges in sentencing. ${ }^{38}$ Second Circuit (and former U.S. District) Judge Jose Cabranes and his wife, Yale law professor Kate Stith, both leading critics of the Guidelines, recently wrote that the Commission has transformed "the venerable ritual of sentencing to a puppet theater in which defendants are not persons, but kinds of persons-abstract entities to be defined by a chart, their concrete existence systematically ignored and thus nullified." ${ }^{\prime 3}$ The Guidelines have not, moreover, eliminated the controversy over disparities in sentencing, but merely shifted the issue to whether such disparities exist with respect to departures from the Guidelines. ${ }^{40}$

The Guidelines themselves were created, and continue to be maintained, by a controversial body, the United States Sentencing Commission. The Commission consists of seven voting members, at least three of whom are required to be sitting federal judges chosen from a pool of six judges nominated by the Judicial Conference of the United

${ }^{34}$ Comptroller General, Report to the Congress of the United States, Reducing Federal Judicial Sentencing and Prosecuting Disparities: A Systematic Approach Needed 9 (1979).

${ }^{35}$ Kate Stith and Jose A. Cabranes, Fear of Judging: Sentencing Guidelines in the Federal Courts 130 (Chicago, 1999).

${ }^{36}$ Id at 83.

${ }^{37}$ Id at 5.

${ }^{38}$ Joan Biskupic and Mary Pat Flaherty, Justice By The Numbers, Wash Post Al (Tuesday, October 8, 1996).

${ }^{39}$ Stith and Cabranes, Fear of Judging at 84 (cited in note 35).

${ }^{40}$ Harvey Berkman, Disparities Still Alive Under Sentencing Guidelines, 20(3) Nat L J A10 (September 15, 1997); David B. Mustard, Racial, Ethnic, and Gender Disparities in Sentencing: Evidence from the U.S. Federal Courts, 44 J L \& Econ 285 (2001). 
States. All the members are chosen by the president and confirmed by the Senate. The members serve six year terms and are removable for cause by the president. The SRA denominated the Commission as "an independent commission in the judicial branch of the United States," a unique status without constitutional precedent. ${ }^{41}$

Although the SRA was passed in 1984, it took the Commission a few years to organize and compile the Guidelines, issuing its final proposed Guidelines in April 1987. The SRA provided for a six month delay to allow Congress to review the proposed Guidelines and the Guidelines thus went into effect on November 1, 1987. They apply to most federal crimes committed after that date. Although many federal judges had opposed the Guidelines, the initial reaction to the final proposal was "muted" as the revisions made to interim drafts had "seemingly mollified" many critics. ${ }^{42}$ Because challenges to the constitutionality of the Guidelines could not occur until the Guidelines were actually applied to determine a sentence, the first constitutional challenges began to appear in early 1988 when the first defendants charged with commission of a crime committed after November 1, 1987, were sentenced.

The criminal defense bar challenged the Guidelines' constitutionality on four grounds. First, defense lawyers charged that the SRA violated the constitution's requirement of separation of powers by placing the Commission, a body which exercised nonjudicial rulemaking powers in constructing the Guidelines, in the judicial branch. Second, defense lawyers argued that the requirement that three members of the Commission be sitting federal judges violated the separation of powers, particularly since the president could remove them from the Commission. Third, the defense bar attacked the Commission's authority to promulgate the Guidelines as an improper delegation of Congressional power. Fourth, the defense bar argued that the Guidelines violated a constitutional due process right to individualized sentencing. (The specifics of the legal arguments are discussed in detail in our earlier paper. ${ }^{43}$ )

The most important feature of these attacks (and the responses by the government's lawyers) for our purpose is that the arguments were made in virtual cookie cutter fashion in case after case. The merits of the legal arguments all turned on the structure of the SRA, not on the facts of the criminal convictions in individual cases. There was thus no significant factual variation from case to case. Moreover, the defense bar

${ }^{41}$ This status was largely driven by the fear that the Supreme Court would strike down the Commission if it was placed outside the judiciary and to make the reforms appear less radical. Stith and Cabranes, Fear of Judging at 45 (cited in note 35).

${ }^{42}$ Id at 57.

${ }^{43}$ Sisk, Heise \& Morriss, 73 NYU L Rev at 1396-1406 (cited in note 3). 
circulated a model brief for use by defense counsel and a small group of government attorneys argued the government case, using briefs whose legal arguments did not change substantially from case to case.

The cases thus present an almost ideal natural experiment in which the judges involved were presented with virtually identical legal questions. Even better, these legal questions were real legal questions, unlike the hypotheticals used in some simulations. ${ }^{44}$ Because of the certainty of prompt Supreme Court review, ${ }^{45}$ the Guidelines cases also lack any element of a judge attempting to maximize his or her utility by creating a legal rule that satisfied personal preferences. ${ }^{46}$ Since the Supreme Court decision would apply to all criminal cases still pending in the trial court or on appeal, the decisions of the district judges would not ultimately govern even the case before them.

One further feature of the legal debate over the Guidelines makes these cases particularly useful. The Reagan Administration was deeply divided over how to respond to the constitutional challenges to the Guidelines. Although President Reagan had signed the SRA in 1984, the Administration was ambivalent over the issue of the location of the Commission and whether the location violated the separation of powers. Consequently, the Administration took the position that while locating the Commission in the judicial branch was in fact unconstitutional, the Commission could be saved by the courts' severing of that one section out of the SRA, relocating the Commission to the executive branch. The Sentencing Commission itself, however, took the position that the SRA was constitutional without such judicial action. As a result, two sets of lawyers responded to each defendant's challenge: one from the Department of Justice and one from the Sentencing Commission. This division allowed us to make a deeper exploration of the separation of powers issues and increased the opportunity for judges to signal their suitability for promotion.

${ }^{44}$ See Sisk, Heise \& Morriss, 73 NYU L Rev at 1385-96 (cited in note 3), for a detailed description of prior studies and their problems.

${ }^{45}$ The circumstances of the Guidelines cases in our database left no doubt in anyone's mind that the question of the constitutionality of the Guidelines and the Commission would be resolved in short order by the U.S. Supreme Court, making the lifespan of a district court decision as capital certain to be short. Although the Supreme Court has the discretion to dodge, and often does dodge, important legal and constitutional issues by declining to review cases that raise those issues, the chaos created by the Guidelines Crisis did not leave that as an option. Federal sentencing of convicted criminals is a high volume business-almost forty-four thousand defendants were convicted in federal courts in 1987, the year immediately prior to the Guidelines taking effect. Statistical Abstract of the United States, 1989. Table 307 at 179. The system could not tolerate uncertainty over the constitutionality of that many sentences.

${ }^{46}$ Judges might, however, have gained some utility from the decision. Judges who found the Guidelines distasteful, for example, might have derived pleasure, however transient, from striking the Guidelines. 
The existing legal precedents on the challenges to the Guidelines left considerable room for district judges to make up their own minds. On the major challenges under separation of powers theory, there was plenty of latitude for argument that either result would be appropriate. On the more tenuous challenges on due process and non-delegation grounds, the precedents were few. If most interpreted the absence of supporting precedent in these areas as signaling that the challenges should fail, a respectable number of judges found otherwise without making patently illegitimate or frivolous arguments. The Guidelines cases thus provide a good test of our signaling theory.

The first district court to consider the constitutional questions issued its ruling on January 25,1988; the last to do so issued its ruling on December 19, 1988. During this time, two cases reached the circuit courts of appeal, which split. The Ninth Circuit invalidated the Guidelines in August 1988 and the Third Circuit sustained the Guidelines in November $1988 .{ }^{47}$ The constitutionality of the Guidelines was settled by the Supreme Court on January 18, 1989 in Mistretta v. United States, ${ }^{48}$ when the Court upheld the Guidelines 8-1 against the nondelegation and separation of powers arguments. (The due process claims were not before the Court; every circuit court of appeals has since rejected the due process claims. ${ }^{49}$ ) The sole dissenting voice on the Court was Justice Scalia, a Reagan appointee.

\section{D A T A}

During 1988, 293 judges rendered 294 decisions on the constitutionality of the Sentencing Guidelines..$^{50}$ Of these, $115(39.1 \%)$ found the Guidelines constitutional and $179(60.9 \%)$ found the Guidelines unconstitutional. $^{51}$

We constructed the database by starting with a list of decisions compiled by the Sentencing Commission staff from the attorneys who par-

${ }^{47}$ Gubeiensio-Ortiz v Kanahele, 857 F2d 1245 (9th Cir. 1988), vacated sub nom, United States v Chavez-Sanchez, 488 US 1036 (1989); United States v Frank, 864 F2d 992 (3rd Cir 1988).

${ }^{48}$ Mistretta v United States, 488 US 361 (1989).

${ }^{49}$ See Sisk, Heise \& Morriss, 73 NYU L Rev at 1458-1459, n 297 (cited in note 3).

${ }^{50}$ The slightly larger number of opinions than judges stems from one judge's issuance of two opinions on the constitutionality of the Guidelines, ruling both that they were constitutional and that they were unconstitutional. We included both of the opinions. Where judges issued later opinions simply repeating their earlier conclusions in a new case, we did not count the later opinions. Cohen used a dataset of 196 judicial decisions. Cohen, 7 JL, Econ, \& Org at 190 (cited in note 4).

${ }^{51}$ Our dataset for this paper draws on the dataset used in the previous study and benefits from the discovery of two additional written opinions that were previously coded as oral decisions and hence reported only the outcome. 
ticipated in the cases and telephone surveys of courts. ${ }^{52}$ We then supplemented this with research on LEXIS and WESTLAW, the computerized databases of judicial opinions. The Sentencing Commission kindly provided us with copies of all decisions of which they had copies. The texts of additional written decisions were located through the online databases and through correspondence with courts. ${ }^{53}$

Three kinds of decisions existed in our universe of 294 decisions. ${ }^{54}$ First, some judges (98) issued individual, written opinions-the usual form of a district court decision on a substantive motion. Second, some judges (90) joined in opinions issued by other district judges through ad hoc joint proceedings. Although unusual for district courts, this resembles the practice of appellate judges who sit in multi-judge panels. For these judges we coded the outcome and the grounds of the decision dependent variables, but not the reasoning method dependent variables (e.g. originalism). Third, some judges (105) issued oral opinions or simply ruled on the issues in a conclusory fashion without indicating how or why they reached their decisions. These judges were coded only on the outcome dependent variable. Two of the three of us then read each opinion independently and coded it for the style of reasoning, the grounds for the decision, and so forth..$^{55}$

We also used a wide range of background variables whose selection was dictated by the existing literature on empirical analysis of judicial decisionmaking including: sex, race, and prior employment experience in a variety of government and legal positions. We used these variables to ensure we controlled for hypothesized effects. We relied on a wide range of published and other sources to compile background information on the judges, described in detail in our prior paper. ${ }^{56}$ Because the age of the district judge may also be a factor in eligibility for promotion to the court of appeals, we have included judges who have taken senior status based upon age and seniority in our

52 The dataset is described in detail in our earlier paper. Sisk, Heise \& Morriss, 73 NYU L Rev at 1417-34 (cited in note 3 ). Accordingly this paper gives only the highlights.

53 We were ultimately unable to obtain copies of opinions for only two judges for whom the records indicate written decisions existed.

${ }^{54}$ We excluded three judges from the database: (1) a district judge from the Virgin Islands for whom crucial data was either unavailable or nonexistent because of his location; (2) a district judge who was included in the Commission's database but whose opinion turned out to not be about the constitutional issues; and (3) a court of appeals judge who ruled as a district court judge sitting by designation, whose position made it impossible to calculate the promotion potential.

${ }^{55}$ Anticipating disagreements, we had established an elaborate mechanism involving the third coauthor and colleagues to resolve any disagreements. We discovered that this was unnecessary since we had no disagreements that required a third party to resolve. This unexpected level of agreement on the coding gives us additional confidence that our codings were not based on subjective readings.

${ }^{56}$ Sisk, Heise \& Morriss, 73 NYU L Rev at 1417-23 (cited in note 3). 
analysis, assigning them the lowest promotion-potential score, as a point of comparison. ${ }^{57}$ We could not directly include the age of district judges as a variable because introducing age and seniority together, which are highly correlated, would cause serious multicollinearity problems. Seniority was chosen over age for two reasons. First, we wished to maintain comparability with earlier work by ourselves and Cohen. Second, we had hypothesized that seniority, which would indicate greater experience under the pre-Guidelines sentencing practice, might predict a higher degree of intensity of feeling, which might be a factor in the decision to write.

Three sets of new variables appear for the first time in this paper. First, we added an additional dependent variable, whether the decision was written or not, to test our signaling hypothesis. We coded a decision as written for all signing judges. ${ }^{58}$ Second, we added additional variables measuring precedent, both in different ways (national vs. circuit, theory vs. outcome) and with different implementations. Third, we added additional variables measuring promotion potential in different ways to provide additional tests of our earlier results.

In our earlier work with this data set we found six main results..$^{59}$ One of the strongest results in both our previous study, and Cohen's, was the significance of variables measuring the potential for promotion to the circuit court of appeals. (See below for a discussion of how

${ }^{57}$ Id at $1426-27$ (cited in note 3 ).

${ }^{58}$ We chose to code in this fashion for two reasons. First, district judges do not generally issue joint opinions. By signing a joint opinion, as opposed to simply issuing an oral ruling from the bench or an order following another judge's opinion, the signing judges went beyond both normal practice and what was necessary to resolve the issue, something we saw as consistent with our signaling model. Unlike appellate panels, where judges might sometimes accede to a colleague's point of view as a courtesy or in exchange for a concession elsewhere due to the repeated nature of appellate dealings, the extraordinary nature and likely singular occurrence of a joint district court opinion suggested both a deeper level of agreement and a desire to communicate joint views on the ultimate question presented. Second, we are measuring only the theory used to evaluate the Guidelines (e.g. due process, separation of powers, and nondelegation), not the judicial philosophy. We thought it implausible that a judge would sign off on an opinion on one of these fundamental issues without an intent to make his or her views on the subject known, while a judge might accept a colleague's reliance on, for example, citations to The Federalist Papers even if the signing judge would have been able to resolve the question without resort to those materials. We did not separately analyze opinion joiners and opinion writers because the decision to join rather than write was often affected by the separate decisions of districts on whether or not to issue a joint opinion. Those decisions were so idiosyncratic that breaking them into separate subgroups reduced the data set size to below usable levels.

${ }^{59}$ Cohen's results, although done before ours, come from only a part of the data set we used and only one of the dependent variables we used. See Cohen, 7 J L, Econ, \& Org 183 (cited in note 4). In general his results are consistent with ours. We will not therefore discuss his results separately except where they differed from ours. 
we constructed this variable.) Both studies found promotion potential strongly influenced judges to uphold the Guidelines. ${ }^{60}$ Exploring the results further, we also found that the influence seemed to be largely related to judges appointed by Democrats. ${ }^{61}$ This result made sense to us because judges appointed by Democrats were more likely to anticipate promotion in a new Democratic administration. Since at the time most of these decisions were issued, Michael Dukakis (who supported the Guidelines) appeared to be the most likely successor to President Reagan, and since the Reagan administration was sharply and publicly divided over the Guidelines, Republican appointed judges would be unsure of what signal to send.

A second strong result in our analysis of outcome was the influence of precedent from other district courts on outcome. (See below for a description of how we measured it.) At the time of the district court opinions there was no direct, binding precedent available from any court on the core constitutional issues. The Supreme Court opinions then available, however, gave strong, although not crystal clear signals, in several areas. On the separation of powers, the pre-1988 Supreme Court opinions from the 1970s and 1980s suggested that the Court took a relatively formal approach to separation of powers issues. This formal approach at least implied that the Guidelines would be in trouble. On the nondelegation issues, that somewhat nebulous doctrine had largely been seen as dead at the federal level but for two dissents by then-Justice Rehnquist in 1980 and 1981 and some academic commentary. On the due process issues, the weight of precedent was strongly, but not conclusively, against the existence of a right to individualized sentencing. As district court opinions accumulated, however, a body of nonbinding precedent addressing precisely the questions at issue in the cases built up. We found the number of decisions within the circuit significant in determining the overall outcome. As we had not at that time measured the precedent on the individual grounds, we were not able to explore the influence of precedent on the other dependent variables.

Ideological variables (e.g. the party of the appointing president, dummy variables for the appointing president) proved generally insignificant with two exceptions. First, Republican appointees in general and Reagan appointees in particular proved less likely to adopt an originalist approach to reasoning. Second, Reagan appointees were less likely to accept the Reagan administration's attempt to relocate the Commission to the executive branch through judicial action.

\footnotetext{
${ }^{60}$ Sisk, Heise \& Morriss, 73 NYU L Rev at 1490 (cited in note 3); Cohen, 12 Intl Rev $\mathrm{L} \&$ Econ at $193-94$ (cited in note 4).

${ }^{61}$ Sisk, Heise \& Morriss, 73 NYU L Rev at 1490-93 (cited in note 3).
} 
Although these results initially surprised us, we were ultimately convinced that both reflected an overarching philosophy of judicial conservatism among Republican appointees. Both overturning the Guidelines or relocating the Commission required a strong degree of what might be seen as judicial activism and originalist reasoning led quite strongly to overturning the Guidelines (13 of 14 district judges who followed the originalist approach invalidated the Guidelines, as did two prominent originalists at the appellate level, Justice Scalia and Judge Alex Kozinski, author of the Ninth Circuit opinion).

In general, background variables like sex, crime rate, attendance at an elite law school, and race were largely irrelevant to determining outcome, reasoning method, or constitutional grounds for action with two major exceptions. First, those minority judges who found the Guidelines unconstitutional were significantly more likely to do so on due process grounds than were white judges, who instead tended to find the Guidelines unconstitutional on separation of powers grounds. $\mathrm{Mi}$ nority judges were not significantly more likely than white judges to find the Guidelines unconstitutional overall. Second, prior employment as a criminal defense attorney proved significant in influencing judges to strike the guidelines, an unsurprising result given the strong negative reaction of the criminal defense bar to the SRA and the Guidelines. ${ }^{62}$ Table 2 describes the variables and Table 3 presents descriptive statistics. Table 4 gives the breakdown of outcomes. Table 5 gives summary statistics for our dependent variables. Two variables require elaboration here: precedent and promotion potential.

We measured promotion potential through three related forms of data. First, we calculated the ratio of circuit court judgeships to district court judges in each state. ${ }^{63} \mathrm{~A}$ higher ratio reflected more opportunities for potential advancement for judges from a given state. Second, we counted the number of current vacancies in the circuit judgeships currently reserved for each state. We counted both unfilled seats and, separately, seats for which there was a pending nomination. Third, we recorded the age of the oldest active circuit court judge from the district judge's state. This measured, albeit imperfectly, the chance of a new vacancy occurring. We hypothesized that

${ }^{62}$ Unlike Cohen, we did not find significant results for prior employment as a government official or, with one exception, to prior employment as a prosecutor. See Cohen, $7 \mathrm{~J} \mathrm{~L}$, Econ, \& Org 183 (cited in note 4). Other prior experience variables such as experience as a law professor or in the military also proved insignificant in most cases. Prior service as a state or local judge was significantly correlated with approval of the Guidelines.

${ }^{63}$ Although circuit court positions are not formally reserved for particular states, there is a strong tradition of allocating them among the states that make up a circuit according to a particular pattern. The allocation does shift over time, however, and we adjusted it based on the ratio at the time of each decision. 
Table 2. Description of Independent Variables

\begin{tabular}{|c|c|}
\hline Variable & Definition \\
\hline OUTCOME & $\begin{array}{l}\text { Judges' decision re: constitutionality of guidelines ( } 1=\text { constitu- } \\
\text { tional) }\end{array}$ \\
\hline SEX & Gender $(1=$ female $)$ \\
\hline RACE & Racial or ethnic origin (1=racial or ethnic minority) \\
\hline LAW-SCHOOL & Graduation from an elite law school ( $1=$ yes) \\
\hline CRIME-RATE & Total state crime index (rate per 100,000 inhabitants), 1988 \\
\hline PARTY & Political party of appointing president ( $1=$ Republican) \\
\hline PROSECUTOR & Prior employment as a government prosecutor ( $1=$ yes) \\
\hline DEFENSE & Prior employment as a defense attorney ( 1 =yes) \\
\hline MILITARY & Prior service in military (1=yes) \\
\hline LAW-PROF & Prior employment as a full-time law professor $(1=y e s)$ \\
\hline POLITICAL & $\begin{array}{l}\text { Prior employment in an elected or appointed political position } \\
\text { (1=yes) }\end{array}$ \\
\hline JUDGE & Prior employment as a state or local judge ( $1=$ yes) \\
\hline $\mathrm{ABA}-\mathrm{AQ}$ & ABA rating of "Well Qualified" or above ( $1=$ yes $)$ \\
\hline$A B A-B Q$ & ABA rating of "Qualified/Not Qualified" or below (l=yes) \\
\hline CASELOAD & Total (civil + criminal) weighted caseload, per judge \\
\hline SENIORITY & Number of months on bench from appointment to date of decision \\
\hline PROMO-POT & Judicial promotion potential factor score \\
\hline PREC-NAT'L & Ratio of con./uncon. guidelines decisions \\
\hline PREC-CIR & Ratio of con./uncon. guidelines decisions within circuit \\
\hline PREC_SBA & $\begin{array}{l}\text { Ratio of con./uncon. guidelines decisions within circuit on sepa- } \\
\text { ration of powers grounds related to location of commission in } \\
\text { the judicial branch }\end{array}$ \\
\hline PREC_SBB & $\begin{array}{l}\text { Ratio of con./uncon. guidelines decisions within circuit circuit on } \\
\text { separation of powers grounds related to location of commission } \\
\text { in the judicial branch }\end{array}$ \\
\hline PREC_SBC & $\begin{array}{l}\text { Ratio of con./uncon. guidelines decisions within circuit circuit on } \\
\text { separation of powers grounds related to location of commission } \\
\text { in the judicial branch }\end{array}$ \\
\hline PREC_SJJ & $\begin{array}{l}\text { Ratio of con./uncon. guidelines decisions within circuit on sepa- } \\
\text { ration of powers grounds related to presence of judges on com- } \\
\text { mission }\end{array}$ \\
\hline PREC_DPA & $\begin{array}{l}\text { Ratio of con./uncon. guidelines decisions within circuit on due } \\
\text { process grounds }\end{array}$ \\
\hline PREC_NDD & $\begin{array}{l}\text { Ratio of con./uncon. guidelines decisions within circuit on non- } \\
\text { delegation grounds }\end{array}$ \\
\hline
\end{tabular}

these three variables were expressions of an underlying and unobserved factor, the promotion potential. We therefore used factor analysis to combine these into a single variable. ${ }^{64}$ We also tested each of these variables individually.

${ }^{64}$ Cohen used a similar procedure in his study. Cohen, 7 J L, Econ, \& Org at 192-93 (cited in note 4). 
Table 3. Descriptive Statistics, Independent Variables

\begin{tabular}{lcc}
\hline Variable & Mean & SD \\
\hline OUTCOME & .39 & .49 \\
SEX & .1 & .29 \\
RACE & .1 & .29 \\
LAW-SCHOOL & .26 & .44 \\
CRIME-RATE & 5983.65 & 1625.86 \\
PARTY & .61 & .49 \\
PROSECUTOR & .41 & .49 \\
DEFENSE & .13 & .34 \\
MILITARY & .62 & .49 \\
LAW-PROF & .04 & .19 \\
POLITICAL & .1 & .29 \\
JUDGE & .37 & .48 \\
ABA-AQ & .51 & .5 \\
ABA-BQ & .06 & .25 \\
CASELOAD & 474.54 & 97.65 \\
SENIORITY & 113.13 & 80.16 \\
PROMO-POT & -.39 & 1.22 \\
PREC-NAT'L & -5.08 & 4.99 \\
PREC-CIR & -1.94 & 4.26 \\
PREC_SBA & 2.27 & 4.23 \\
PREC_SBB & 6.85 & 8.37 \\
PREC_SBC & 4.25 & 5.62 \\
PREC_SII & 2.20 & 4.09 \\
PREC_DPA & .38 & 2.45 \\
PREC_NDD & -2.75 & 6.45 \\
\hline & & \\
\hline
\end{tabular}

For precedent, we created a series of variables that measured the number of other judges ruling on the issue in question in the same circuit and nationally. Although the vast majority of the precedents discussed by the courts in the course of their opinions were Supreme Court opinions rather than circuit court opinions, we nonetheless measured circuit level precedent as well as national level precedent because we believed that judges were more likely to give weight to persuasive opinions written by the judges they knew best. We therefore thought that a judge in California, for example, would be more likely to give weight to an opinion from another judge in the Ninth Circuit than to one from a judge in the east coast Second Circuit. ${ }^{65}$

To create the precedent variables, we sorted the opinions into date order within each circuit. We then calculated the number of judges

${ }^{65}$ We considered, but rejected as unworkable, a within-district measure of precedent because there insufficient opinions in many districts to implement it. In addition, districts vary from the tiny to the huge, while circuits are closer to being of similar size. 
Table 4. Summary Statistics on Outcome \& Whether Judge Wrote an Opinion

\begin{tabular}{|c|c|c|c|c|c|}
\hline & Con. & Uncon. & Write & Did NotWrite & $(N)$ \\
\hline Decision & $115(.39)$ & $179(.61)$ & $191(.65)$ & $103(.35)$ & 294 \\
\hline Con. & - & - & $64(.56)$ & $51(.44)$ & 115 \\
\hline Uncon. & - & - & $127(.71)$ & $52(.29)$ & 179 \\
\hline \multicolumn{6}{|l|}{ By Sex } \\
\hline Male & $105(.40)$ & $161(.61)$ & $175(.66)$ & $91(.34)$ & 266 \\
\hline Female & $10(.36)$ & $18(.64)$ & $16(.57)$ & $12(.43)$ & 28 \\
\hline \multicolumn{6}{|l|}{ By Race/Ethnicity } \\
\hline White (non-Hispanic) & $107(.40)$ & $159(.60)$ & $170(.64)$ & $96(.36)$ & 266 \\
\hline (other) & $8(.29)$ & $20(.71)$ & $21(.75)$ & $7(.25)$ & 28 \\
\hline \multicolumn{6}{|l|}{ By Law School } \\
\hline Elite Law School & $25\{.33\}$ & $50(.67)$ & $43(.57)$ & $32(.43)$ & 75 \\
\hline Non-Elite Law School & $90\{.41\}$ & $129(.59)$ & $148(.68)$ & $71(.32)$ & 219 \\
\hline \multicolumn{6}{|c|}{ By Party of Appointing President } \\
\hline Republican & $75(.42)$ & $103(.58)$ & $114(.64)$ & $64(.36)$ & 178 \\
\hline Democrat & $40(.35)$ & $76(.66)$ & $77(.66)$ & $39(.34)$ & 116 \\
\hline \multicolumn{6}{|l|}{ By Employment } \\
\hline \multicolumn{6}{|l|}{ Prosecutor } \\
\hline Yes & $48(.40)$ & $72(.60)$ & $70(.58)$ & $50(.42)$ & 120 \\
\hline No & $67(.39)$ & $107(.62)$ & $121(.70)$ & $53(.31)$ & 174 \\
\hline \multicolumn{6}{|l|}{ Defense Lawyer } \\
\hline Yes & $10(.26)$ & $29(.74)$ & $25(.64)$ & $14(.36)$ & 39 \\
\hline No & $105(.41)$ & $150(.59)$ & $166(.65)$ & $89(.35)$ & 255 \\
\hline \multicolumn{6}{|l|}{ Military } \\
\hline Yes & $67(.37)$ & $115(.63)$ & $120(.66)$ & $62(.34)$ & 182 \\
\hline No & $48(.43)$ & $64(.57)$ & $71(.63)$ & $41(.37)$ & 112 \\
\hline \multicolumn{6}{|l|}{ Law Professor } \\
\hline Yes & $3(.27)$ & $8(.73)$ & $8(.73)$ & $3(.27)$ & 11 \\
\hline No & $112(.40)$ & $171(.60)$ & $183(.65)$ & $100(.35)$ & 283 \\
\hline \multicolumn{6}{|l|}{ Political Experience } \\
\hline Yes & $11(.39)$ & $17(.61)$ & $23(.82)$ & $5(.18)$ & 28 \\
\hline No & $104(.39)$ & $162(.61)$ & $168(.63)$ & $98(.37)$ & 266 \\
\hline \multicolumn{6}{|c|}{ 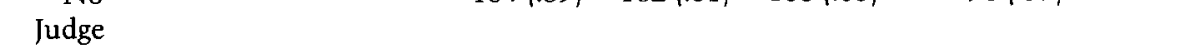 } \\
\hline Yes & $49\{.45\}$ & $59(.55)$ & $73(.68)$ & $35(.32)$ & 108 \\
\hline No & $66(.36)$ & $120(.65)$ & $118(.63)$ & $68(.37)$ & 186 \\
\hline \multicolumn{6}{|l|}{ By ABA Rating } \\
\hline Above Qualified & $56(.38)$ & $93(.62)$ & $96(.64)$ & $53(.36)$ & 149 \\
\hline Qualified & $53(.42)$ & $72(.58)$ & $82(.66)$ & $43(.34)$ & 125 \\
\hline Below Qualified & $6(.32)$ & $13(.68)$ & $12(.63)$ & $7(.37)$ & 19 \\
\hline
\end{tabular}

holding the Guidelines constitutional and unconstitutional at least seven days prior to the date of each opinion. We used the seven-day rule to allow time for the opinions to be disseminated. Because judges sometimes ruled from the bench in Guidelines cases and then issued their formal opinions justifying their decisions a short time later, we also sought to ensure that we did not erroneously attribute knowledge 
Table 5. Summary Statistics on Dependent Variables

\begin{tabular}{lcrr}
\hline & Con. & Uncon. & (N) \\
\hline All Judges & $115(.39)$ & $179(.61)$ & 294 \\
Constitutional Claims & & & \\
SOP-Branch Location & $63(.36)$ & $114(.64)$ & 177 \\
SOP-Judge Members & $60(.35)$ & $113(.65)$ & 173 \\
Non-Delegation Doctrine & $91(.68)$ & $42(.32)$ & 133 \\
Due Process Claim & $31(.43)$ & $42(.58)$ & 73 \\
\hline Written Opinion & Yes & No & \\
\cline { 2 - 4 } & $191(.65)$ & $103(.35)$ & 294 \\
\hline
\end{tabular}

of an opinion to a judge when the judge's mind had been made up prior to the opinion's issuance. We used the number of judges rather than the number of opinions because some courts issued multi-judge opinions. Finally, we wanted the variable to reflect whether prior decisions were strongly in one direction or not, reasoning that it would be much more difficult to go against a larger weight of authority than where the other judges had been more closely divided.

We therefore settled on a formula of $(x-y)^{\star}|x-y| /(x+y)$ where $x$ is the number of judges who decided at least seven days prior to the decision that the Guidelines were constitutional on a particular ground and $\mathrm{y}$ is the equivalent number deciding they were unconstitutional. Thus, for example, where there were three decisions deciding the guidelines were constitutional and seven deciding that they were unconstitutional, the variable would be $(3-7)^{\star}|3-7| / 10=-1.60$. Using the absolute value preserved the sign while allowing us to effectively square the numerator, to give greater weight to larger differences in opinions. We created fourteen precedent variables, one each for each dependent variable by circuit and nationally. We also experimented with alternative forms of measuring precedent, using ratios of decisions rather than the formula described above.

\section{RE S ULTS}

Our results fall into two categories and are presented in Tables 6-9. First, we found evidence of signaling in judges' decisions to issue written opinions. Second, while we confirmed our prior findings ${ }^{66}$ that judges were influenced by the weight of prior District Court decisions

${ }^{66}$ Sisk, Heise \& Morriss, 73 NYU L Rev at $1496-98$ (cited in note 3). 
Table 6. Probability of a Written Judicial Opinion (Written Opinion = 1)

Standard

\section{Demographic}

SEX

$-.76$

(.51)

RACE

.66

(.53)

LAW-SCHOOL

$-.55$

(.31)

CRIME-RATE

$-.00$

(8.80) (e-05)

\section{Political}

PARTY

$-.02$

(.31)

Prior Employment

PROSECUTOR $-.65^{*}$

(.29)

DEFENSE

.16

(.42)

MILITARY

$-.18$

(.31)

LAW-PROF

$-.07$

$(.75)$

$\begin{array}{ll}\text { POLITICAL } & .99\end{array}$

(.59)

JUDGE $\quad .26$

(.30)

Judicial Role or Institution

.03

ABA-AQ

(.29)

ABA-BQ

$-.61$

(.58)

CASELOAD

$-1.86$

(1.67)

SENIORITY

.00

$(.00)$

Promotion Potential

PROMO-POT

$.26^{*}$

(.13)

Precedent

PREC-CIR

\section{Outcome}

DEC

$-.70^{*}$

(.28)

(constant)

2.21 * *

(.79)

$\%$ accurately predicted by model

66.67

McFadden's pseudo $\mathrm{R}^{2}$

$\mathrm{N}$

.10

291

\footnotetext{
${ }^{*} \mathrm{p}<.05 ;{ }^{* *} \mathrm{p}<.01$
} 
Table 7. Outcome Results

\begin{tabular}{|c|c|c|c|c|}
\hline & (1) & (2) & (3) & (4) \\
\hline \multicolumn{5}{|l|}{ Demographic } \\
\hline SEX & $\begin{array}{l}-.56 \\
(.50)\end{array}$ & $\begin{array}{l}-.53 \\
(.51)\end{array}$ & $\begin{array}{l}-.65 \\
(.50)\end{array}$ & $\begin{array}{l}-.63 \\
(.50)\end{array}$ \\
\hline RACE & $\begin{array}{l}-.68 \\
(.50)\end{array}$ & $\begin{array}{l}-.72 \\
(.50)\end{array}$ & $\begin{array}{l}-.60 \\
(.50)\end{array}$ & $\begin{array}{l}-.64 \\
(.50)\end{array}$ \\
\hline LAW-SCHOOL & $\begin{array}{l}-.17 \\
(.31)\end{array}$ & $\begin{array}{l}-.11 \\
(.32)\end{array}$ & $\begin{array}{c}-.29 \\
\{.31\}\end{array}$ & $\begin{array}{l}-.23 \\
(.31)\end{array}$ \\
\hline CRIME-RATE & $\begin{array}{l}-2.5(\mathrm{e}-05) \\
(8.35)(\mathrm{e}-05)\end{array}$ & $\begin{array}{l}-7.7(\mathrm{e}-05) \\
\{8.89)(\mathrm{e}-05)\end{array}$ & $\begin{array}{l}-2.9(\mathrm{e}-05) \\
(8.36)(\mathrm{e}-05)\end{array}$ & $\begin{array}{l}-7.5(\mathrm{e}-05) \\
(8.83)(\mathrm{e}-05)\end{array}$ \\
\hline \multicolumn{5}{|l|}{ Political } \\
\hline PARTY & $\begin{array}{l}.24 \\
(.29)\end{array}$ & $\begin{array}{l}.20 \\
(.29)\end{array}$ & $\begin{array}{l}.16 \\
(.29)\end{array}$ & $\begin{array}{l}.12 \\
(.29)\end{array}$ \\
\hline \multicolumn{5}{|l|}{ Prior Employment } \\
\hline PROSECUTOR & $\begin{array}{l}.25 \\
(.28)\end{array}$ & $\begin{array}{l}.30 \\
(.28)\end{array}$ & $\begin{array}{l}.16 \\
(.27)\end{array}$ & $\begin{array}{l}.23 \\
(.28)\end{array}$ \\
\hline DEFENSE & $\begin{array}{l}-.75 \\
|.43|\end{array}$ & $\begin{array}{l}-.90^{*} \\
(.44)\end{array}$ & $\begin{array}{l}-.73 \\
\mid .43\}\end{array}$ & $\begin{array}{l}-.85 \\
(.44)\end{array}$ \\
\hline MILITARY & $\begin{array}{l}-.28 \\
(.30)\end{array}$ & $\begin{array}{l}-.34 \\
(.30)\end{array}$ & $\begin{array}{l}-.34 \\
(.29)\end{array}$ & $\begin{array}{l}-.40 \\
(.30)\end{array}$ \\
\hline LAW-PROF & $\begin{array}{l}-.53 \\
(.72)\end{array}$ & $\begin{array}{l}-.49 \\
(.73)\end{array}$ & $\begin{array}{l}-.56 \\
(.72)\end{array}$ & $\begin{array}{l}-.52 \\
(.73)\end{array}$ \\
\hline POLITICAL & $\begin{array}{l}.12 \\
(.45)\end{array}$ & $\begin{array}{l}.14 \\
(.45)\end{array}$ & $\begin{array}{l}-.00 \\
(.45)\end{array}$ & $\begin{array}{l}.02 \\
|.45|\end{array}$ \\
\hline JUDGE & $\begin{array}{l}.62^{*} \\
(.28)\end{array}$ & $\begin{array}{l}.60^{*} \\
(.28)\end{array}$ & $\begin{array}{l}.58^{\star} \\
(.27)\end{array}$ & $\begin{array}{l}.55^{*} \\
(.27)\end{array}$ \\
\hline \multicolumn{5}{|l|}{ Judicial Role or Institution } \\
\hline $\mathrm{ABA}-\mathrm{AQ}$ & $\begin{array}{l}-.19 \\
(.27)\end{array}$ & $\begin{array}{l}-.18 \\
(.27)\end{array}$ & $\begin{array}{l}-.13 \\
\{.27\}\end{array}$ & $\begin{array}{l}-.13 \\
(.27)\end{array}$ \\
\hline $\mathrm{ABA}-\mathrm{BQ}$ & $\begin{array}{l}-.59 \\
(.58)\end{array}$ & $\begin{array}{l}-.58 \\
(.59)\end{array}$ & $\begin{array}{l}-.49 \\
\{.58\}\end{array}$ & $\begin{array}{l}-.48 \\
(.59)\end{array}$ \\
\hline CASELOAD & $\begin{array}{l}-.00 \\
(.00)\end{array}$ & - & $\begin{array}{l}-.00 \\
(.00)\end{array}$ & - \\
\hline CRIM-CASELOAD & - & $\begin{array}{r}3.42^{*} \\
(1.64)\end{array}$ & - & $\begin{array}{l}3.23^{*} \\
(1.64)\end{array}$ \\
\hline SENIORITY & $\begin{array}{l}.00 \\
(.00)\end{array}$ & $\begin{array}{l}.00 \\
(.00)\end{array}$ & $\begin{array}{l}.00 \\
(.00)\end{array}$ & $\begin{array}{l}.00 \\
(.00)\end{array}$ \\
\hline \multicolumn{5}{|l|}{ Promotion Potential } \\
\hline PROMO-POT & $\begin{array}{l}.29^{*} \\
(.12)\end{array}$ & $\begin{array}{l}.25^{*} \\
(.12)\end{array}$ & $\begin{array}{l}.30^{*} \\
(.13)\end{array}$ & $\begin{array}{l}.29^{*} \\
(.13)\end{array}$ \\
\hline \multicolumn{5}{|l|}{ Precedent } \\
\hline CIRCUIT PRECEDENT ${ }^{+}$ & $\begin{array}{l}.07^{*} \\
(.03)\end{array}$ & $\begin{array}{l}.07^{*} \\
(.03)\end{array}$ & - & - \\
\hline NATIONAL PRECEDENT ${ }^{*}$ & - & - & $\begin{array}{l}-.02 \\
(.03)\end{array}$ & $\begin{array}{l}-.03 \\
(.03)\end{array}$ \\
\hline (constant) & $\begin{array}{l}.49 \\
(.99)\end{array}$ & $\begin{array}{l}-.30 \\
(.73)\end{array}$ & $\begin{array}{c}.16 \\
(1.01)\end{array}$ & $\begin{array}{l}-.41 \\
(.76)\end{array}$ \\
\hline $\begin{array}{l}\% \text { accurately predicted } \\
\text { by model }\end{array}$ & 63.92 & 68.04 & 63.45 & 65.17 \\
\hline McFadden's pseudo $\mathrm{R}^{2}$ & .06 & .07 & .05 & .06 \\
\hline $\mathbf{N}$ & 291 & 291 & 290 & 290 \\
\hline
\end{tabular}

${ }^{*} \mathrm{p}<.05 ;{ }^{* *} \mathrm{p}<.01$.

-Definition of variable based upon dependent variable; values differ across columns. 


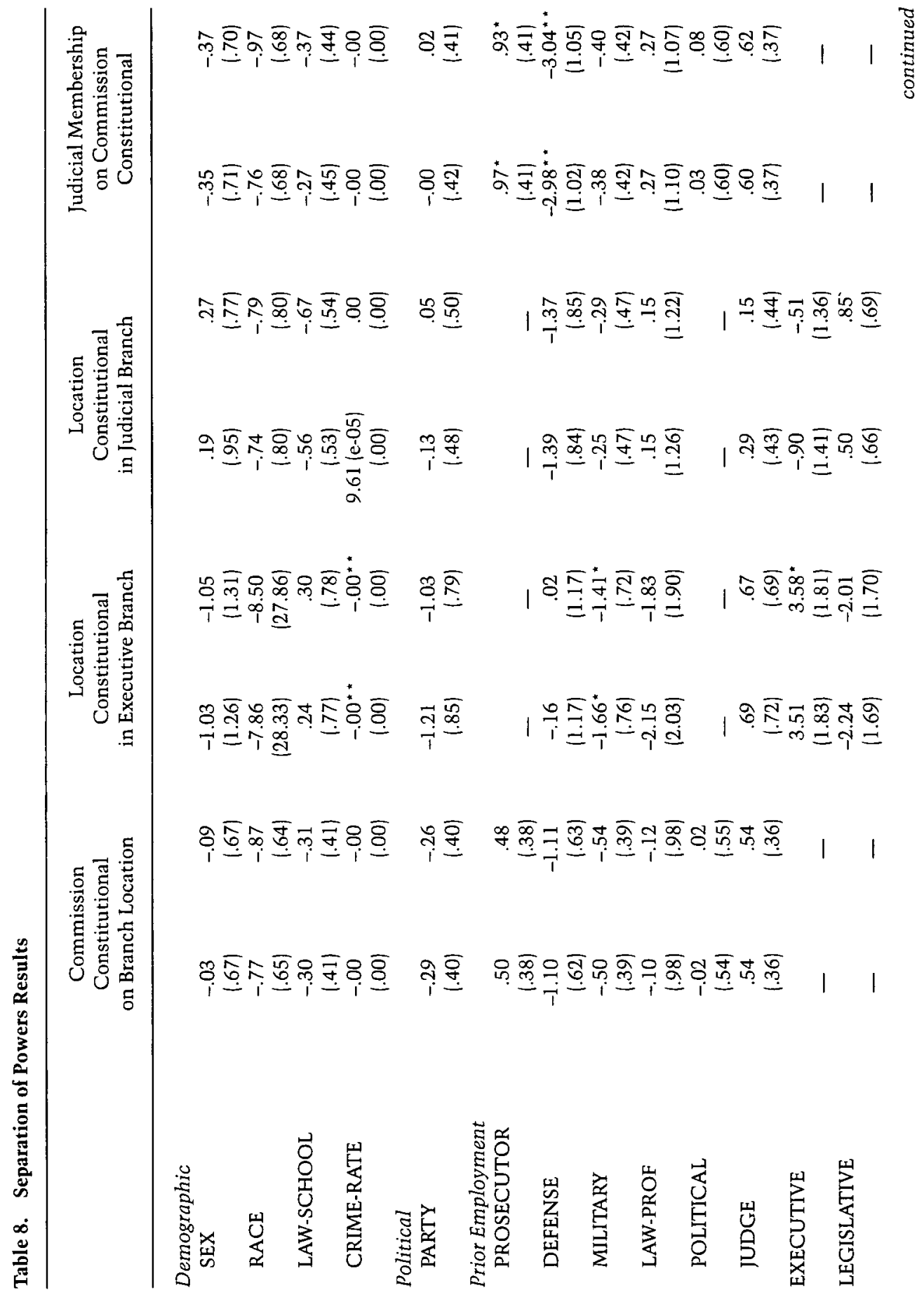




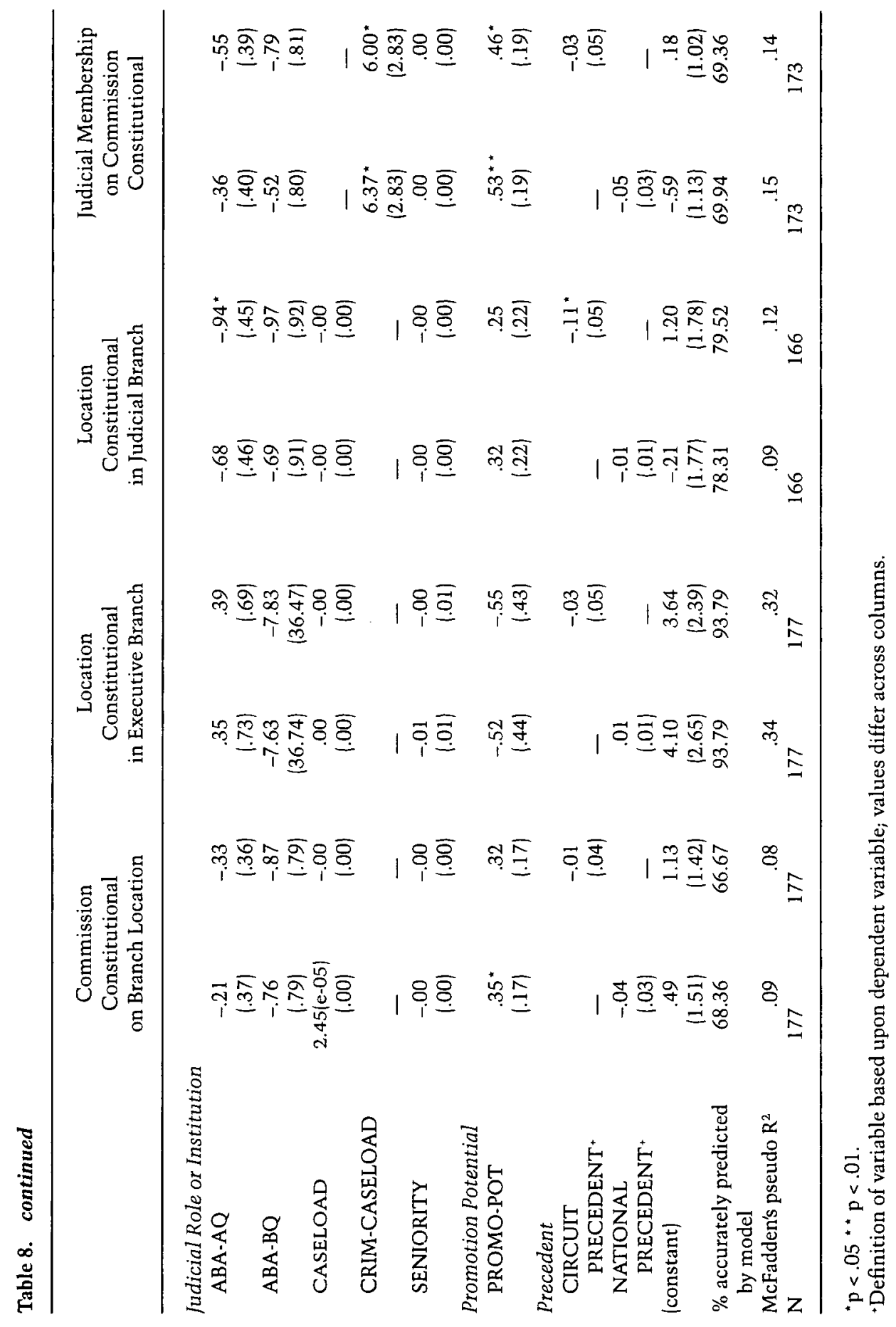


Table 9. Nondelegation \& Due Process Challenges Results

\begin{tabular}{|c|c|c|c|c|}
\hline & \multicolumn{2}{|c|}{ Nondelegation Theory } & \multicolumn{2}{|c|}{ Due Process Theory } \\
\hline \multicolumn{5}{|l|}{ Demographic } \\
\hline SEX & $\begin{array}{c}-.17 \\
\{1.03\}\end{array}$ & $\begin{array}{l}-1.06 \\
\{1.10\}\end{array}$ & $\begin{array}{c}1.37 \\
(1.51)\end{array}$ & $\begin{array}{c}1.30 \\
(1.51)\end{array}$ \\
\hline RACE & $\begin{array}{l}-.13 \\
\mid .98\}\end{array}$ & $\begin{array}{c}-.38 \\
(1.03)\end{array}$ & $\begin{array}{l}-3.91^{*} \\
(1.49)\end{array}$ & $\begin{array}{c}-3.83^{* *} \\
(1.49)\end{array}$ \\
\hline LAW-SCHOOL & $\begin{array}{l}-.31 \\
\mid .54)\end{array}$ & $\begin{array}{c}-.71 \\
(.59)\end{array}$ & $\begin{array}{r}-1.49 \\
(.92)\end{array}$ & $\begin{array}{r}-1.44 \\
(.89)\end{array}$ \\
\hline CRIME-RATE & $\begin{array}{c}-6.1(\mathrm{e}-05) \\
(.00)\end{array}$ & $\begin{array}{c}-7.6(\mathrm{e}-05) \\
(.00)\end{array}$ & $\begin{array}{l}-.00 \\
(.00)\end{array}$ & $\begin{array}{l}-.00 \\
1.00 \mid\end{array}$ \\
\hline \multicolumn{5}{|l|}{ Political } \\
\hline PARTY & $\begin{array}{l}.16 \\
(.51)\end{array}$ & $\begin{array}{c}.56 \\
(.58)\end{array}$ & $\begin{array}{l}.15 \\
(.91)\end{array}$ & $\begin{array}{l}.23 \\
(.93)\end{array}$ \\
\hline \multicolumn{5}{|l|}{ Prior Employment } \\
\hline PROSECUTOR & $\begin{array}{l}-.76 \\
(.50)\end{array}$ & $\begin{array}{l}-.92 \\
(.55)\end{array}$ & $\begin{array}{c}.50 \\
|.72|\end{array}$ & $\begin{array}{l}.59 \\
(.72)\end{array}$ \\
\hline DEFENSE & $\begin{array}{l}-.37 \\
(.72)\end{array}$ & $\begin{array}{c}-.24 \\
(.73)\end{array}$ & $\begin{array}{c}-3.34^{\star} \\
(1.50)\end{array}$ & $\begin{array}{c}-3.39 \\
(1.50)\end{array}$ \\
\hline MILITARY & $\begin{array}{l}-.70 \\
(.58)\end{array}$ & $\begin{array}{l}-.76 \\
(.62)\end{array}$ & $\begin{array}{l}.15 \\
(.74)\end{array}$ & $\begin{array}{l}.17 \\
(.74)\end{array}$ \\
\hline LAW-PROF & $\begin{array}{c}7.20 \\
(23.63)\end{array}$ & $\begin{array}{c}8.08 \\
(22.50)\end{array}$ & $\begin{array}{c}1.40 \\
(1.67)\end{array}$ & $\begin{array}{c}1.39 \\
(1.66)\end{array}$ \\
\hline POLITICAL & $\begin{array}{l}.13 \\
(.66)\end{array}$ & $\begin{array}{c}.40 \\
(.76)\end{array}$ & $\begin{array}{c}-.77 \\
(1.92)\end{array}$ & $\begin{array}{c}-.23 \\
(1.83)\end{array}$ \\
\hline JUDGE & $\begin{array}{l}.42 \\
(.51)\end{array}$ & $\begin{array}{l}.74 \\
(.55)\end{array}$ & $\begin{array}{c}.43 \\
(.71)\end{array}$ & $\begin{array}{l}.40 \\
(.71)\end{array}$ \\
\hline \multicolumn{5}{|l|}{ Judicial Role or Institution } \\
\hline ABA-AQ & $\begin{array}{l}-.93 \\
(.49)\end{array}$ & $\begin{array}{c}-1.67^{* *} \\
(.57)\end{array}$ & $\begin{array}{r}-1.44^{\star} \\
(.72\}\end{array}$ & $\begin{array}{r}-1.35 \\
(.72)\end{array}$ \\
\hline $\mathrm{ABA}-\mathrm{BQ}$ & $\begin{array}{l}-1.85 \\
(1.13)\end{array}$ & $\begin{array}{l}-2.85^{*} \\
(1.25)\end{array}$ & $\begin{array}{r}.08 \\
1.35\end{array}$ & $\begin{array}{c}.30 \\
(1.40)\end{array}$ \\
\hline CASELOAD & $\begin{array}{c}.00 \\
\{.00\}\end{array}$ & $\begin{array}{c}.00 \\
(.00)\end{array}$ & $\begin{array}{l}.01 \\
(.01)\end{array}$ & $\begin{array}{l}.01 \\
(.01)\end{array}$ \\
\hline CRIM-CASELOAD & - & - & - & - \\
\hline SENIORITY & $\begin{array}{c}.00 \\
(.00)\end{array}$ & $\begin{array}{l}.00 \\
(.00 \mid\end{array}$ & $\begin{array}{l}-.01 \\
(.01)\end{array}$ & $\begin{array}{l}-.01 \\
(.01)\end{array}$ \\
\hline \multicolumn{5}{|l|}{ Promotion Potential } \\
\hline PROMO-POT & $\begin{array}{l}.97^{*} \\
(.29)^{*}\end{array}$ & $\begin{array}{l}.94 * \\
(.32)\end{array}$ & $\begin{array}{l}.07 \\
(.37)\end{array}$ & $\begin{array}{l}-.09 \\
(.41)\end{array}$ \\
\hline \multicolumn{5}{|l|}{ Precedent } \\
\hline CIRCUIT PRECEDENT ${ }^{+}$ & $\begin{array}{l}-.12 \\
(.07)\end{array}$ & - & $\begin{array}{l}-.02 \\
\{.14\}\end{array}$ & - \\
\hline NATIONAL PRECEDENT ${ }^{+}$ & - & $\begin{array}{l}-.17^{*} \\
(.05)\end{array}$ & - & $\begin{array}{l}-.07 \\
\mid .08\}\end{array}$ \\
\hline (constant) & $\begin{array}{c}1.53 \\
\{2.17\}\end{array}$ & $\begin{array}{c}4.14 \\
(2.47)\end{array}$ & $\begin{array}{c}-.50 \\
(3.16)\end{array}$ & $\begin{array}{c}-.49 \\
\{3.16\}\end{array}$ \\
\hline $\begin{array}{l}\% \text { accurately predicted } \\
\text { by model }\end{array}$ & 79.70 & 78.20 & 76.71 & 76.71 \\
\hline McFadden's pseudo $\mathrm{R}^{2}$ & .29 & .36 & .33 & .34 \\
\hline $\mathrm{N}$ & 133 & 133 & 73 & 73 \\
\hline
\end{tabular}

" $\mathrm{p}<.05 ;{ }^{* *} \mathrm{p}<.01$.

-Definition of variable based upon dependent variable; values differ across columns. 
one way or the other on the Guidelines within a circuit, that persuasive precedent effect on the general outcome did not extend to a persuasive precedent effect on the individual doctrinal issues raised in these cases. Thus, once we have understood persuasive precedential weight in a more nuanced way, the importance of signaling as an explanatory theory here is reinforced.

\section{A. Signals}

Table 6 gives the results for the regression evaluating the decision to write. Three variables were significant: greater promotion potential increased the likelihood of writing, a decision that the guidelines were constitutional decreased the likelihood of writing, and background as a criminal prosecutor decreased the likelihood of writing.

The results with respect to promotion potential are consistent with our hypothesis that written opinions serve as a signal to appointing authorities. In high profile cases like these, judges' opinions and decisions were certain to be closely scrutinized. Moreover, because of the relative vagueness of the existing Supreme Court precedent, how a judge dealt with the issues in these cases was a particularly good signal. Finally, the gain in judicial utility from creating a precedent was zero, or close to it, because of the certainty of Supreme Court review. While we cannot eliminate the possibility that writing an opinion in these cases may have been more exciting or pleasurable than, say, writing one on a routine discovery matter, the nature of the opinions supports the signaling hypothesis.

A constitutional decision was less likely to produce a written opinion than an unconstitutional decision-a reassuring result. Judges ought to be more likely to explain their reasoning when they strike a statute as unconstitutional, particularly a statute as important as the Sentencing Reform Act. This result is also consistent with the signaling hypothesis. A decision upholding the guidelines sends a fairly clear signal by itself-the judge has rejected all the grounds for challenging the statute. A decision to strike the guidelines, on the other hand, does not send a clear signal. A judge might agree, for example, with one of the separation of powers challenges to the SRA but not with the due process or nondelegation doctrine challenges. Given the relative theoretical pedigrees of the theories, explaining his or her views about the merits of each of the challenges could be an important means of clarifying the signal. Indeed, we observed precisely this behavior in some of the opinions: judges upheld the SRA on one ground but struck it on another. The results concerning former prosecutors' decreased likelihood of writing do not have a natural explanation.

Also interesting is what was not significant: none of our demo- 
graphic, political, or other variables produced significant results. In some cases this is surprising. For example, former law professors ought, at least according to our experience, to be expected to be more likely to write. Similarly, graduates of elite law schools or those with higher ABA ratings might be thought more likely to wish to share their thoughts with the world than those from lesser schools or with lower $\mathrm{ABA}$ ratings.

\section{B. Precedent}

Although the overall level of support for the guidelines within the circuit was significant in predicting the outcome, the individual doctrinal precedents were insignificant, except in the somewhat puzzling case of the judicial branch location theory where they exercised a negative influence. Cohen, who used a different measure of precedent and a subset of the data used here, found that the presence of one or more prior unconstitutional decisions in the same judicial district was related to a negative constitutional outcome. ${ }^{67}$ At the same time, however, he found that a ratio of constitutional to unconstitutional decisions in the district was not significant. ${ }^{68}$ Cohen's explanation was that the politically safe decision was to uphold the guidelines until a colleague provided political cover. ${ }^{69}$

Our interpretation of the results differs from Cohen's. Voting to strike the guidelines as unconstitutional was not a particularly politically risky decision. The Reagan Administration, as noted above, was divided over the constitutionality of the Guidelines and was forced to argue that plain language in the statute about branch location was merely precatory and should be ignored by the judges, a step that could be seen as demanding a high degree of judicial activism. Although Michael Dukakis, the actual or presumed Democratic presidential candidate and presumed next president for much of the period in question, had endorsed the Guidelines, they were not a policy closely identified with him. Upholding the guidelines might curry favor with an incoming-Dukakis administration but was unlikely to make or break a judge's relationship with the new administration. ${ }^{70}$

Moreover, if political cover were the issue, it should matter what theory the other judges acted on. Both the nondelegation and due process claims required judges to take actions out of the judicial mainstream. No statute had been struck by the federal courts on nondele-

${ }^{67}$ Cohen, 7 J L, Econ, \& Org at $195-96$ (cited in note 4).

${ }^{68}$ Id at $194-96$.

${ }^{69}$ Id at 196.

${ }^{70}$ An opinion under such circumstances allowed the judge to signal his or her broader judicial philosophy more clearly than the result standing alone would. 
gation grounds since the New Deal, for example. Further, both the nondelegation and due process theories relied heavily on completely untested interpretations of the constitution. For example, the nondelegation argument relied on a theory of a nondelegable duty in Congress to set sentencing ranges as well as the more "conventional" nondelegation doctrine articulated in the 1930s. Even the Reagan Administration's position encouraged what could be viewed as judicial activism to save the Guidelines, an approach that might, at least for conservative jurists, make judges wish for political cover, yet our results were significantly negative in that analysis. Issue-specific precedent variables testing that theory were not significant, however. Thus, where the decision required more political cover, going out on a limb to relocate the Commission to the executive branch or to strike it as unconstitutional on the non-delegation or due process grounds, we found no evidence of an impact in the hypothesized direction. Political cover, therefore, does not appear to be a meaningful interpretation of the role of precedent in these cases.

Perhaps the relatively unique nature of the legal questions presented by these cases offers the best explanation. The issues confronting the judges in these cases were ones that turned on how to read a limited universe of Supreme Court precedents and other materials, such as the Federalist Papers and other Founding documents. Deciding the issues required the judges to come to grips with that set of materials, regardless of whether or how they read other judges' interpretations of the materials. Once having come to grips with the original materials, however, there was little reason to rely on another's interpretation. A judge who had worked through whether he thought, for example, that the participation of judges on the commission rendered it unconstitutional would have thought through the issues sufficiently well that the "weight" of district court precedent on the point would not be likely to have much influence. Rather the role of the other district courts' opinions was just what it should be in a system of persuasive precedent: an opinion would persuade the judge to consider a particular argument about how to interpret the agreed sources and prompt him to consider the sources independently.

Finally, in the sentencing guidelines context, it was apparent to all early on that the key and most practical question simply was whether the guidelines were constitutional or not. The answer to this question dictated how sentencing would be conducted until the Supreme Court resolved the question. The desire to be in step with one's peers that Cohen hypothesizes would express itself most strongly on the overall outcome rather than the specific grounds. Thus it is understandable, and perhaps even to be expected, that judges would take primary notice of the overall breakdown between prior decisions that 
held the guidelines constitutional versus unconstitutional. It also suggests that the manner in which a judge takes notice of precedent on some questions at least, or perhaps how precedent filters into the judge's mind, is likely to be at a broader level rather than at a deep analytical level.

This comports with the nature of the constraint imposed by precedent. If a precedent requires deep thought to understand, it is either not clearly written or is ambiguous in its dictates. It would not, therefore, function as a binding constraint. A clear precedent from a higher court, on the other hand, is straightforward to apply.

This use of precedent is consistent with the results we found (although the results are undoubtedly consistent with other theories as well). Additional opinions, particularly by judges from the same circuit and so likely known to the writer, would be useful in suggesting lines of inquiry to be pursued while reading the Supreme Court precedents and Founding documents. Thus more opinions tending in one direction would influence indirectly the conclusions of judges coming to the overall question later. The weight of decisions on particular points, however, would not be something that would determine the later judge's reasoning - that would be something reached through his or her independent analysis of the materials.

This analysis fits the use of precedent in the opinions. Only a few judges wrote opinions simply adopting other judges' analyses. Most judges who wrote, wrote their own opinions in which they acknowledged points made by other judges, noted district court precedent that agreed or disagreed, but resolved the question by a focus on the primary sources. Again, this style of opinion is inconsistent with the political cover explanation suggested by Cohen's results. Judges who wanted cover could hardly hope for a better position than to simply adopt another's opinion. Judges who wanted cover would also be expected to rely more heavily on arguments based on the increasing percentage of judges opting to hold the guidelines unconstitutional, a form of argument relatively rare in the opinions.

Finally, a persuasive precedent approach is consistent with the behavior of the judges in writing the opinions. Judges clearly cared deeply about the sentencing guidelines and the constitutional issues they raised. Their approach to the opinions was largely a thoughtful and reasoned one-we encountered few frivolous arguments and few poorly written opinions. It is unlikely that the judges thought the Supreme Court would pay close attention to their written opinions, although there was a chance that the overwhelming "vote" against the guidelines by district judges, who manned the front lines on sentencing, would influence the Court. They wrote, therefore, to persuade their colleagues on the district court bench and, perhaps, to 
document their position on the issues raised by the Guidelines that struck so close to home for the judges.

This leaves us with the one case where the new doctrinal precedent variable proved significant and negative: the issue of whether the Commission could be constitutionally located in the judicial branch of government. At the risk of explaining the inexplicable, our explanation of this result is as follows. In general we found that many of the district judges resented the Guidelines as an intrusion on their independence. This resentment showed itself most strongly in their reaction to the Sentencing Commission's argument that the Commission was part of the judicial branch rather than an outside imposition. ${ }^{71}$ Thus when confronted with a district court taking both the minority position that the Guidelines were constitutional and the even smaller minority position that the Commission was part of the judiciary, judges were directly reminded of everything they disliked about the Commission and the Guidelines. Thus a pro-Commission opinion on branch location was a potent "in your face" symbol that provoked greater resistance.

\section{CONCLUSIONS}

Our results yield insights in both the areas of the impact of opinions as signals and the role of precedent. Signaling appears to be a viable explanation for the decision to write in at least some circumstances and further work is needed to identify its role more completely. We also continue to find significant results in general for our promotion potential variable with our augmented dataset and more thorough controls for precedent. Together with Cohen's earlier papers, this result suggests a need for closer attention to the opportunity for "advancement" within the judiciary as an influence on judicial decisionmaking. First, we need a better measure of promotion potential capable of focusing on those judges who indeed desire it or are considered eligible for it. Second, given that the findings here and in Cohen's papers deal with federal judges who are relatively insulated from the chances for promotion, those state judges who are elected are obvious candidates for further study in this regard.

${ }^{71}$ This resentment showed itself in a number of ways. One of us was told by the Commission staff that they experienced difficulty in getting judges to report sentencing data to the Commission as required by law and that judges refused to concede that the Commission was in the judicial branch in the way that the Administrative Office is. Judges' protective instincts sometimes even extended to the $\mathrm{AO}$-another of us has heard of judges refusing to attend sessions at the mandatory circuit conferences in the 1980s or submit statistical forms to the AO on the grounds that neither of these things are mentioned in Article III of the Constitution. 
With respect to precedent, we have taken the first steps toward empirically identifying the manner in which precedent acts, at least in this type of case. Precedent is likely to have different impacts in different areas of the law (fact dependent, multi-factor balancing tests vs. bright line rules) and at different levels of the court system. Nonetheless, it appears to be significant at the level one might suspect is least likely to matter: among judges of the same level and who are not bound to pay attention to it. 
